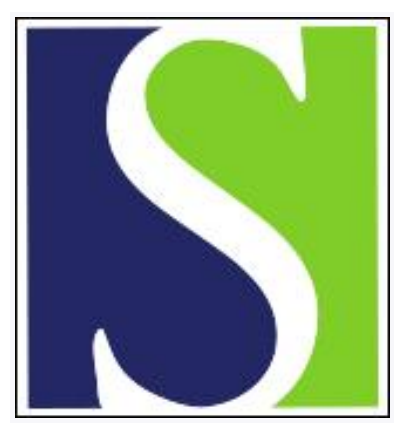

Scand J Work Environ Health 1986;12(5):448-454

https://doi.org/10.5271/sjweh.2113

Issue date: Oct 1986

Mortality of workers exposed to 2 methyl-4 chlorophenoxyacetic acid.

by Coggon D, Pannett B, Winter PD, Acheson ED, Bonsall J

This article in PubMed: www.ncbi.nlm.nih.gov/pubmed/3787216

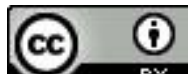




\title{
Mortality of workers exposed to 2 methyl-4 chlorophenoxyacetic acid
}

\author{
by David Coggon, PhD, MRCP, ${ }^{1}$ Brian Pannett, MSc, ${ }^{1}$ Paul D Winter, MSc, ${ }^{1}$ \\ E Donald Acheson, DM, FRCP, ${ }^{1}$ John Bonsall, MFOM ${ }^{2}$
}

\begin{abstract}
COGGON D, PANNETT B, WINTER PD, ACHESON ED, BONSALL J. Mortality of workers exposed to 2 methyl-4 chlorophenoxyacetic acid. Scand J Work Environ Health 12 (1986) 448-454. The authors examined the mortality and cancer incidence of employees at a company which has manufactured, formulated, and sprayed 2 methyl-4 chlorophenoxyacetic acid (MCPA) and other phenoxy acid herbicides. Ninety-eight percent of the 5784 men employed by the company during 1947-1975 was traced to the end of 1983. The overall mortality of the cohort was less than that of the national population, as was mortality from cancer. When allowance was made for rural residence, the deficit of cancer deaths became a slight excess, but not statistically significantly so. Among workers whose jobs entailed potential exposure to MCPA, there was one death from soft tissue sarcoma ( 0.6 expected). No further cases of soft tissue sarcoma were registered among living members of the cohort. Three potentially exposed workers died from nasal carcinoma, but this tumor has not previously been associated with phenoxy herbicides and the cluster of cases may have occurred by chance. The findings do not exclude the possibility that MCPA is a human carcinogen, but they suggest that any risk of soft tissue sarcoma is less than that indicated by earlier studies of 2,4,5-T (2,4,5-trichlorophenoxyacetic acid) and 2,4,5-trichlorophenol and is small
\end{abstract} in absolute terms.

Key terms: phenoxy acids, 2,4,5-T, 2,4,5-trichlorophenoxyacetic acid, soft tissue sarcoma, lymphoma, nasal carcinoma.

Since their discovery in the early 1940 s, the phenoxy acid herbicides have found wide use in many countries, both in agriculture and in forestry. They have also been sold for use in gardens, mainly as lawn weedkillers. Among the compounds in the group are 2,4,5trichlorophenoxyacetic acid $(2,4,5-\mathrm{T}), 2$,4-dichlorophenoxyacetic acid (2,4-D), and 2 methyl-4 chlorophenoxyacetic acid (MCPA). Commercial preparations of $2,4,5-\mathrm{T}$ have in the past contained traces of $2,3,7,8$ tetrachlorodibenzo-para-dioxin (2,3,7,8-TCDD), a substance which is highly toxic in several animal species (11) and which is also an animal carcinogen (12, 17). Other phenoxy acids may be contaminated by less toxic dioxin isomers, but not by 2,3,7,8-TCDD.

Epidemiologic studies have linked exposure to phenoxy acids and structurally related chlorophenols with the occurrence of soft tissue sarcomas and lymphomas (1). However, almost all the published data concern subjects exposed to 2,4,5-T or its precursor in the manufacture of 2,4,5-trichlorophenol. It is

1 Environmental Epidemiology Unit of the Medical Research Council, Southampton General Hospital, Southampton SO9 4XY, United Kingdom.

2 FBC Ltd, Hauxton, Cambridge CB2 5HU, United Kingdom.

Reprint requests to: Dr D Coggon, MRC Environmental Epidemiology Unit, Southampton General Hospital, Southampton SO9 4XY, United Kingdom. unclear whether the hazard, if any, extends to products other than those contaminated by $2,3,7,8$-TCDD. To explore this question, we have carried out a retrospective survey of mortality and cancer incidence among the workforce of a British company which has both manufactured and sprayed MCPA.

\section{Subjects and methods}

The company under study manufactured MCPA from 1947 until 1982. The process entailed the condensation of orthocresol with sodium monochloroacetate to form sodium cresoxyacetate, which was then acidified and reacted with gaseous chlorine to give MCPA. Production was carried out at a single site with most of the workforce drawn from the local rural population. Several other agricultural chemicals were made at the factory during the same period, the most important being copper oxychloride (1943-1972), dinitroorthocresol (1943-1962), and a variety of organophosphorus insecticides (1948 on) and chlortriazine herbicides (1964 on). In addition many other products were bought in and formulated, including, at times, 2,4,5-T and other phenoxy acids. However, in comparison with MCPA, 2,4,5-T was handled on only a small scale.

Until 1972 the company also operated an aerial and tractor-mounted spraying service from depots scattered over a wide area of rural Britain. The range of chemi- 
cals sprayed was similar to that handled in production and formulation, but their use was seasonal. Phenoxy acids (principally MCPA) were applied extensively during the months from March to August, but 2,4,5-T was virtually never used. Because the work was seasonal, many of the spray operatives were employed for periods of less than six months.

The study cohort comprised all men employed by the company at its factory or spray depots between 1 January 1947 and 31 December 1975. We identified the cohort from personnel records, and for each employee abstracted the full name, date of birth, address, dates of starting and finishing work, and details of jobs held. On the basis of recorded job title (and in the case of spray operatives, dates of employment), we then classified workers according to their potential exposure to phenoxy acids. Three grades of exposure were distinguished - "high," "low," and "background." Jobs entailing high exposure comprised principally chemical process workers, spray operatives, and certain laboratory occupations. Those with low exposure included maintenance staff and workers in chemical stores and transport. Background exposure was assigned to clerical and sales staff and to managers who did not normally enter the chemical production area. In spraying operations exposure would only have occurred during the spring and summer. Occasionally, where workers had changed their job in the course of their employment, only the most recent occupation was available from the personnel records. When assigning exposure, we assumed that earlier jobs held by these men were similar (in terms of exposure) to the occupation that was known.

Members of the cohort were traced through the National Health Service (NHS) Central Register at Southport (supplemented if necessary by reference to the $\mathrm{Na}$ tional Insurance Index at Newcastle Upon Tyne), and their vital status on 31 December 1983 was determined. The Office of Population Censuses and Surveys provided us with copies of the death certificates of those men who had died, with the underlying cause of death coded to the ninth revision of the International Classification of Diseases (ICD). In addition, we obtained details of any cancers that had been registered among the cohort members during the period of follow-up.

Expected numbers of deaths by cause were calculated by the person-years method using national (England and Wales) death rates for men by age and calendar period. As a large proportion of workers were resident in rural areas at the time of their employment, we derived a second set of expected numbers adjusted by the cause-specific standardized mortality ratio (SMR) for aggregated rural areas of England and Wales during the period 1968-1978. Neither of these reference sets is ideal, but in the context of cancer mortality the most appropriate comparison is likely to lie somewhere between the two. Tests of statistical significance and confidence limits were calculated by the usual methods based on the Poisson distribution.

\section{Results}

A total of 5784 employees satisfied the entry criteria for the study, but $30(0.5 \%)$ could not be included in the analysis because either their date of birth or date of joining the company was not available from the personnel records. A further 98 men $(1.7 \%)$ could not be traced in the NHS Central Register, and could only be followed to the date on which they left the company. Two hundred and fifty-six subjects emigrated during the period of follow-up and were followed to their date of embarkation.

Of the 5754 employees included in the analysis, 4078 were considered to have greater than "background" exposure to phenoxy acids (table 1). More than half of these men had worked in potentially exposed jobs for at least six months.

Overall mortality in the cohort was less than that expected from national rates, as was mortality from all neoplasms, from heart disease, and from disease of the respiratory system (table 2). Death rates from injury and poisoning and from gastrointestinal disorders were slightly elevated, but not to the point of statistical significance. On application of the rural correction factor, the deficit of deaths from cancer became a slight excess, but again it was not statistically significant.

More detailed analysis showed that most of the common types of cancer occurred less frequently in the workforce than in the general population (table 3). Small excesses of prostatic carcinoma (18 deaths observed, 13.5 expected) and brain cancer (11 deaths observed, 8.7 expected) were not statistically significant. The observation of 14 deaths from leukemia (8.0 expected) was more striking, but five of the cases occurred in men with only background exposure to phenoxy acids, and a breakdown of the leukemias by histological type was unremarkable (four chronic lymphatic leukemia, four acute myeloid leukemia, three chronic myeloid leukemia, two acute monocytic leukemia, and one unspecified leukemia). There were three deaths from nasal cancer ( 0.7 expected), all in men with probable exposure to phenoxy acids. Two had worked as spray operatives (for two and three months, respectively), and the third had been employed for six months as a process operator in chemical manufacture. One of the spray operatives was recorded

Table 1. Potential exposure to phenoxy acids among subjects included in the analysis of mortality and cancer incidence.

\begin{tabular}{lcccc}
\hline $\begin{array}{l}\text { Type of potential } \\
\text { exposure }\end{array}$ & $\begin{array}{c}<1 \\
\text { month }\end{array}$ & $\begin{array}{c}1-6 \\
\text { months }\end{array}$ & $\begin{array}{c}>6 \\
\text { months }\end{array}$ & Total \\
\hline $\begin{array}{l}\text { Manufacture } \\
\text { and formulation }\end{array}$ & 137 & 388 & 1020 & 1545 \\
$\begin{array}{l}\text { Application } \\
\text { Any a }\end{array}$ & 322 & 1128 & 1111 & 2561 \\
\hline
\end{tabular}

a Twenty-eight men were potentially exposed both in manufacture and spraying. A further 1676 subjects were considered to have had only background exposure. 
Table 2. Observed and expected deaths in the major disease categories. (SMR = standardized mortality ratio, $95 \% \mathrm{Cl}=95 \%$ confidence interval.)

\begin{tabular}{|c|c|c|c|c|c|c|c|}
\hline \multirow{2}{*}{ Disease category a } & \multirow{2}{*}{$\begin{array}{l}\text { Observed } \\
\text { deaths }\end{array}$} & \multicolumn{3}{|c|}{ From national rates } & \multicolumn{3}{|c|}{$\begin{array}{l}\text { From national rates with } \\
\text { rural correction factor }\end{array}$} \\
\hline & & $\begin{array}{l}\text { Expected } \\
\text { deaths }\end{array}$ & SMR & $95 \% \mathrm{Cl}$ & $\begin{array}{l}\text { Expected } \\
\text { deaths }\end{array}$ & SMR & $95 \% \mathrm{Cl}$ \\
\hline $\begin{array}{l}\text { All causes of death }(0-999) \\
\text { All neoplasms }(140-239) \\
\text { Hypertensive and ischemic }\end{array}$ & $\begin{array}{r}1039 \\
297\end{array}$ & $\begin{array}{r}1232.9 \\
314.0\end{array}$ & $\begin{array}{l}84 \\
95\end{array}$ & $\begin{array}{l}79-89 \\
84-106\end{array}$ & $\begin{array}{r}1134.3 \\
276.3\end{array}$ & $\begin{array}{r}92 \\
107\end{array}$ & $\begin{array}{l}86-97 \\
96-120\end{array}$ \\
\hline $\begin{array}{l}\text { heart disease }(401-414,428-429) \\
\text { Respiratory disease }(460-519)\end{array}$ & $\begin{array}{r}337 \\
93\end{array}$ & $\begin{array}{l}414.9 \\
152.8\end{array}$ & $\begin{array}{l}81 \\
61\end{array}$ & $\begin{array}{l}73-90 \\
49-75\end{array}$ & $\begin{array}{l}390.0^{b} \\
126.8^{b}\end{array}$ & $\begin{array}{l}86 \\
73\end{array}$ & $\begin{array}{l}77-96 \\
59-90\end{array}$ \\
\hline Digestive disease $(520-579)$ & 35 & 33.1 & 106 & $74-147$ & $\ldots \mathrm{c}$ & . & . \\
\hline Injury and poisoning (800-999) & 77 & 71.6 & 108 & $85-134$ & $\ldots c$ & . & . \\
\hline
\end{tabular}

a Code of the International Classification of Diseases (ICD), ninth revision, in parentheses.

b The rural correction factor for hypertensive and ischemic heart disease was from data for hypertensive, ischemic, and other nonrheumatic heart disease (ICD 401-416, 420-429).

c Rural correction factors for digestive disease and injury and poisoning were not available.

Table 3. Observed and expected deaths from cancer. (SMR = standardized mortality ratio, $95 \% \mathrm{Cl}=95 \%$ confidence interval.)

\begin{tabular}{|c|c|c|c|c|c|c|c|c|}
\hline \multirow{2}{*}{ Cancer $^{a}$} & \multirow{2}{*}{$\begin{array}{l}\text { Observed } \\
\text { deaths }\end{array}$} & \multicolumn{3}{|c|}{ From national rates } & \multicolumn{4}{|c|}{$\begin{array}{l}\text { From national rates with } \\
\text { rural correction factor }\end{array}$} \\
\hline & & $\begin{array}{l}\text { Expected } \\
\text { deaths }\end{array}$ & SMR & $95 \% \mathrm{Cl}$ & $\begin{array}{l}\text { Expected } \\
\text { deaths }\end{array}$ & SMR & $95 \%$ & \\
\hline Tongue (141) & 1 & 1.04 & 96 & $2-534$ & 0.89 & 112 & $3-$ & 623 \\
\hline Pharynx (146-149) & 1 & 2.19 & 46 & $1-255$ & 1.84 & 54 & $1-$ & 303 \\
\hline Esophagus (150) & 8 & 8.87 & 90 & $39-178$ & 8.52 & 94 & $41-$ & 185 \\
\hline Stomach (151) & 26 & 33.34 & 78 & $51-114$ & 28.67 & 91 & $59-$ & 133 \\
\hline Small intestine (152) & 1 & 0.65 & 154 & $4-859$ & 0.63 & 159 & $4-$ & 884 \\
\hline Large intestine (153) & 19 & 18.97 & 100 & $60-156$ & 18.59 & 102 & $62-$ & 160 \\
\hline Rectum (154) & 8 & 14.30 & 56 & $24-110$ & 13.58 & 59 & $25-$ & 116 \\
\hline Gall bladder and bile ducts (156) & 2 & 1.86 & 107 & $13-388$ & 1.67 & 119 & $14-$ & 432 \\
\hline Pancreas (157) & 9 & 13.27 & 68 & $31-129$ & 12.47 & 72 & $33-$ & 137 \\
\hline \multicolumn{9}{|l|}{ Peritoneum and retroperitoneal } \\
\hline $\begin{array}{l}\text { tissue }(158) \\
\text { Nose }(160)\end{array}$ & 3 & 0.70 & 429 & $88-1253$ & 0.61 & $\begin{array}{l}273 \\
493\end{array}$ & $102-1$ & 440 \\
\hline Larynx (161) & 4 & 2.98 & 134 & $37-343$ & 2.29 & 174 & $48-$ & 446 \\
\hline \multicolumn{9}{|l|}{ Lung, pleura and mediastinum } \\
\hline$(162-164)$ & 117 & 126.81 & 92 & $76-111$ & 101.45 & 115 & $95-$ & 138 \\
\hline Bone (170) & 1 & 1.22 & 82 & $2-455$ & 1.12 & 89 & $2-$ & 496 \\
\hline Soft tissue sarcoma (171) & 1 & 0.94 & 106 & $3-593$ & 0.96 & 104 & $3-$ & 581 \\
\hline Melanoma of skin (172) & 1 & 1.96 & 51 & $1-285$ & 2.02 & 50 & $1-$ & 276 \\
\hline Other skin cancer (173) & 3 & 0.97 & 309 & $64-904$ & 0.98 & 306 & $63-$ & 895 \\
\hline Prostate (185) & 18 & 13.51 & 133 & $79-211$ & 13.65 & 132 & $78-$ & 208 \\
\hline Testis (186) & 4 & 1.69 & 236 & $64-605$ & 1.79 & 223 & $61-$ & 572 \\
\hline Other male genital organs (187) & 1 & 0.50 & 201 & $5-1118$ & 0.44 & 227 & $6-12$ & 266 \\
\hline Bladder (188) & 8 & 11.13 & 72 & $31-142$ & 9.46 & 85 & $37-$ & 167 \\
\hline Kidney (189) & 5 & 5.63 & 89 & $29-207$ & 5.07 & 99 . & $32-$ & 230 \\
\hline \multicolumn{9}{|l|}{ Brain and nervous system } \\
\hline$(191-192)$ & 11 & 8.69 & 127 & $63-227$ & 8.86 & 124 & $62-$ & 222 \\
\hline Thyroid (193) & 1 & 0.57 & 177 & $4-984$ & 0.59 & 170 & $4-$ & 949 \\
\hline \multicolumn{9}{|l|}{ Non-Hodgkin's lymphoma } \\
\hline$(200,202)$ & 2 & 5.53 & 36 & $4-131$ & 5.36 & 37 & $5-$ & 135 \\
\hline Hodgkin's disease (201) & 1 & 3.51 & 28 & $1-159$ & 3.44 & 29 & $1-$ & 162 \\
\hline Multiple myeloma (203) & 5 & 3.09 & 162 & $53-377$ & 3.09 & 162 & $53-$ & 378 \\
\hline Leukemia (204-208) & 14 & 8.00 & 175 & $96-294$ & 7.92 & 177 & $97-$ & 297 \\
\hline
\end{tabular}

a Code of the International Classification of Diseases (ICD), ninth revision, in parentheses. In addition to the cancers shown three deaths were ascribed to brain tumors of unspecified malignancy (ICD 239.6); two to carcinoma of the suprarenal gland (ICD 194); one each to carcinoma of the parotid (ICD 142), bleeding cerebral angioma (ICD 228) and multiple renal tract papillomas (ICD 223); and 12 to carcinomatosis of unknown origin (ICD 199).

on his death certificate as having worked more recently as a carpenter.

Mortality ratios tended to be somewhat higher when rural correction factors were applied, but in essence the findings were similar.
Analyses by grade and duration of potential exposure to phenoxy acids (tables 4 and 5), and allowing for a latency of 5 or 10 years from the time of first exposure (table 6), did not suggest any further disease associations. 
Table 4. Mortality from selected cancers by grade of potential exposure to phenoxy acids. ${ }^{2}$

\begin{tabular}{|c|c|c|c|c|c|c|c|c|c|}
\hline \multirow{3}{*}{ Cancer } & \multicolumn{9}{|c|}{ Grade of potential exposure ${ }^{b}$} \\
\hline & \multicolumn{3}{|c|}{ Background } & \multicolumn{3}{|c|}{ Low } & \multicolumn{3}{|c|}{ High } \\
\hline & 0 & $\mathrm{SMR}_{\mathrm{N}}$ & $\mathrm{SMR}_{\mathrm{R}}$ & 0 & $\mathrm{SMR}_{\mathrm{N}}$ & $\mathrm{SMR}_{\mathrm{R}}$ & 0 & $\mathrm{SMR}_{\mathrm{N}}$ & $\mathrm{SMR}_{\mathrm{F}}$ \\
\hline Esophagus & 4 & 122 & 127 & 3 & 113 & 118 & 1 & 34 & 35 \\
\hline Stomach & 13 & 99 & 115 & 6 & 59 & 69 & 7 & 69 & 81 \\
\hline Large intestine & 11 & 151 & 155 & 4 & 70 & 71 & 4 & 67 & 68 \\
\hline Rectum & 2 & 36 & 38 & 4 & 93 & 98 & 2 & 45 & 47 \\
\hline Gall bladder and bile ducts & 1 & 141 & 156 & - & 0 & 0 & 1 & 168 & 188 \\
\hline Pancreas & 2 & 40 & 43 & 1 & 25 & 27 & 6 & 139 & 147 \\
\hline Nose & - & 0 & 0 & - & 0 & 0 & 3 & 1249 & 1437 \\
\hline Larynx & - & 0 & 0 & 1 & 111 & 144 & 3 & 318 & 414 \\
\hline Lung, pleura and mediastinum & 39 & 83 & 103 & 35 & 90 & 113 & 43 & 105 & 132 \\
\hline Soft tissue sarcoma & - & 0 & 0 & - & 0 & 0 & 1 & 280 & 272 \\
\hline Skin (other than melanoma) & 2 & 507 & 508 & 1 & 346 & 341 & - & 0 & 0 \\
\hline 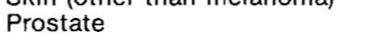 & 7 & 117 & 116 & 6 & 142 & 140 & 5 & 151 & 150 \\
\hline Testis & 1 & 209 & 197 & 2 & 427 & 401 & 1 & 134 & 126 \\
\hline Bladder & 3 & 67 & 79 & 1 & 29 & 34 & 4 & 123 & 145 \\
\hline Kidney & 3 & 151 & 168 & - & 0 & 0 & 2 & 101 & 112 \\
\hline Brain and nervous system & 5 & 182 & 179 & 2 & 80 & 79 & 4 & 116 & 113 \\
\hline Non-Hodgkin's lymphoma & - & 0 & 0 & 2 & 124 & 127 & - & 0 & 0 \\
\hline Hodgkin's disease & - & 0 & 0 & 1 & 100 & 102 & - & 0 & 0 \\
\hline Multiple myeloma & 1 & 90 & 90 & 2 & 215 & 215 & 2 & 191 & 190 \\
\hline Leukemia & 5 & 180 & 182 & 3 & 127 & 128 & 6 & 210 & 213 \\
\hline
\end{tabular}

a Where a subject worked in several jobs, he was classified according to that with the highest grade of exposure.

b $\mathrm{O}=$ observed number of deaths, $\mathrm{SMR}_{\mathrm{N}}=$ standardized mortality ratio based on national rates, $\mathrm{SMR}_{\mathrm{R}}=$ standardized mortality ratio based on national rates with rural correction factor.

Table 5. Mortality from selected cancers by duration of potential exposure to phenoxy acids. (Subjects with background exposure only have been excluded.)

\begin{tabular}{|c|c|c|c|c|c|c|c|c|c|}
\hline \multirow{3}{*}{ Cancer } & \multicolumn{9}{|c|}{ Duration of potential exposure ${ }^{a}$} \\
\hline & \multicolumn{3}{|c|}{$<1$ month } & \multicolumn{3}{|c|}{$1-6$ months } & \multicolumn{3}{|c|}{$>6$ months } \\
\hline & 0 & $\mathrm{SMR}_{\mathrm{N}}$ & $\mathrm{SMR}_{\mathrm{R}}$ & 0 & $\operatorname{SMR}_{N}$ & $\mathrm{SMR}_{\mathrm{R}}$ & 0 & $\operatorname{SMR}_{N}$ & $\mathrm{SMR}_{\mathrm{f}}$ \\
\hline Esophagus & 1 & 198 & 204 & 2 & 103 & 107 & 1 & 32 & 33 \\
\hline Stomach & 1 & 55 & 64 & 2 & 28 & 33 & 10 & 88 & 102 \\
\hline Large intestine & - & 0 & 0 & 6 & 147 & 150 & 2 & 31 & 31 \\
\hline Rectum & 1 & 126 & 133 & 2 & 66 & 69 & 3 & 61 & 64 \\
\hline Gall bladder and bile ducts & - & 0 & 0 & 1 & 248 & 278 & $\underline{-}$ & 0 & 0 \\
\hline Pancreas & _- & 0 & 0 & 3 & 104 & 110 & 4 & 86 & 91 \\
\hline Nose & - & 0 & 0 & 3 & 1914 & 2155 & - & 0 & 0 \\
\hline Larynx & - & 0 & 0 & 2 & 314 & 406 & 2 & 194 & 252 \\
\hline Lung, pleura and mediastinum & 7 & 97 & 122 & 25 & 91 & 113 & 46 & 103 & 128 \\
\hline Soft tissue sarcoma & - & 0 & 0 & 1 & 442 & 426 & - & 0 & 0 \\
\hline Skin (other than melanoma) & - & 0 & 0 & 1 & 494 & 495 & - & 0 & 0 \\
\hline Prostate & - & 0 & 0 & 5 & 191 & 189 & 6 & 141 & 139 \\
\hline Testis & - & 0 & 0 & - & 0 & 0 & 3 & 495 & 464 \\
\hline Bladder & - & 0 & 0 & 3 & 129 & 152 & 2 & 53 & 63 \\
\hline Kidney & - & 0 & 0 & 1 & 78 & 87 & 1 & 49 & 55 \\
\hline Brain and nervous system & - & 0 & 0 & 1 & 47 & 46 & 5 & 155 & 152 \\
\hline Non-Hodgkin's lymphoma & 1 & 283 & 295 & - & 0 & 0 & 1 & 50 & 52 \\
\hline Hodgkin's disease & - & 0 & 0 & - & 0 & 0 & 1 & 79 & 80 \\
\hline Multiple myeloma & - & 0 & 0 & 1 & 145 & 145 & 3 & 271 & 270 \\
\hline Leukemia & 3 & 592 & 594 & 2 & 107 & 108 & 4 & 142 & 143 \\
\hline
\end{tabular}

a $\mathrm{O}=$ observed number of deaths, $\mathrm{SMR}_{\mathrm{N}}=$ standardized mortality ratio based on national rates, $\mathrm{SMR}_{\mathrm{R}}=$ standardized mortality ratio based on national rates with rural correction factor.

Only one death from soft tissue sarcoma (ICD 171) was recorded during the period of follow-up. The man in question had worked as a spray operative for six months 18 years before his death. The cause of death, certified as a spindle cell neurilemmal sarcoma, has been confirmed by independent expert review of the tumor histology. We also obtained histological material from the tumors of two patients whose deaths were ascribed to retroperitoneal cancer (ICD 158), but neither of these tumors turned out to be a soft tissue sarcoma. One was a carcinoma, and the other a myeloid sarcoma.

Three subjects died from malignant lymphomas (ICD 200-202) as compared with approximately nine 
Table 6. Mortality from selected cancers allowing for latencies of 0,5 , and 10 years from first exposure. (Subjects with background exposure only have been excluded.)

\begin{tabular}{|c|c|c|c|c|c|c|c|c|c|}
\hline \multirow{3}{*}{ Cancer } & \multicolumn{9}{|c|}{ Latency ${ }^{a}$} \\
\hline & \multicolumn{3}{|c|}{0 years } & \multicolumn{3}{|c|}{5 years } & \multicolumn{3}{|c|}{10 years } \\
\hline & 0 & $\mathrm{SMR}_{\mathrm{N}}$ & $\mathrm{SMR}_{R}$ & 0 & $\mathrm{SMR}_{\mathrm{N}}$ & $\mathrm{SMR}_{\mathrm{R}}$ & 0 & $\mathrm{SMR}_{\mathrm{N}}$ & $\mathrm{SMR}_{\mathrm{R}}$ \\
\hline Esophagus & 4 & 72 & 75 & 4 & 74 & 77 & 4 & 79 & 82 \\
\hline Stomach & 13 & 64 & 75 & 12 & 63 & 74 & 12 & 70 & 82 \\
\hline Large intestine & 8 & 68 & 70 & 8 & 72 & 74 & 7 & 69 & 70 \\
\hline Rectum & 6 & 69 & 72 & 6 & 72 & 76 & 6 & 79 & 83 \\
\hline Gall bladder and bile ducts & 1 & 86 & 96 & 1 & 91 & 101 & 1 & 99 & 110 \\
\hline Pancreas & 7 & 84 & 89 & 6 & 75 & 80 & 5 & 68 & 72 \\
\hline Nose & 3 & 670 & 766 & 3 & 716 & 821 & 3 & 799 & 907 \\
\hline Larynx & 4 & 217 & 282 & 4 & 229 & 297 & 3 & 187 & 244 \\
\hline Lung, pleura and mediastinum & 78 & 98 & 122 & 72 & 95 & 118 & 63 & 90 & 113 \\
\hline Soft tissue sarcoma & 1 & 159 & 156 & 1 & 177 & 175 & 1 & 204 & 200 \\
\hline Skin (other than melanoma) & 1 & 174 & 171 & 1 & 183 & 180 & 1 & 202 & 198 \\
\hline Prostate & 11 & 146 & 144 & 11 & 149 & 147 & 10 & 141 & 140 \\
\hline Testis & 3 & 247 & 232 & 2 & 218 & 205 & 2 & 326 & 309 \\
\hline Bladder & 5 & 75 & 88 & 4 & 62 & 73 & 4 & 67 & 78 \\
\hline Kidney & 2 & 55 & 61 & 2 & 58 & 64 & 2 & 63 & 70 \\
\hline Brain and nervous system & 6 & 101 & 99 & 6 & 111 & 109 & 5 & 108 & 106 \\
\hline Non-Hodgkin's lymphoma & 2 & 55 & 56 & 2 & 59 & 61 & 2 & 67 & 69 \\
\hline Hodgkin's disease & 1 & 41 & 42 & - & 0 & 0 & - & 0 & 0 \\
\hline Multiple myeloma & 4 & 202 & 202 & 4 & 209 & 209 & 4 & 225 & 225 \\
\hline Leukemia & 9 & 173 & 174 & 7 & 150 & 151 & 6 & 149 & 151 \\
\hline
\end{tabular}

a $\mathrm{O}=$ observed number of deaths, $\mathrm{SMR}_{\mathrm{N}}=$ standardized mortality ratio based on national rates, $\mathrm{SMR}_{\mathrm{R}}=$ standardized mortality ratio based on national rates with rural correction factor.

deaths expected in the total cohort. Among workers with likely exposure to phenoxy acids six deaths from lymphoma would have been expected.

\section{Discussion}

Suspicion that phenoxy acids or their contaminants cause cancer first arose from the observation in northern Sweden of seven cases of soft tissue sarcoma among men who had been occupationally exposed to phenoxy herbicides (5). Subsequently the association was supported by two Swedish case-referent studies (2, 8 ) and by follow-up of employees at plants in the United States where 2,4,5-T or 2,4,5-trichlorophenol had been manufactured (10). However, doubts have been raised about the possible effects of recall bias in the Swedish investigations (1) and about the accuracy of certified causes of death in the American cohort studies (3). More recent research has been less conclusive. A case-referent study of soft tissue sarcoma in New Zealand has shown only a weak and statistically nonsignificant association with reported exposure to phenoxy acids (16), and studies in the United States have failed to demonstrate an increased risk of soft tissue tumors among Vietnam veterans exposed to Agent Orange (a 1:1 mixture of 2,4,5-T and 2,4-D) (4, 13). In Victoria, Australia, follow-up of 2181 state employees who sprayed 2,4-D and 2,4,5-T during the years 1951 to 1970 has shown one death from soft tissue sarcoma with 0.7 expected (15).

To date, most investigations have concentrated on subjects with exposure to $2,4,5$-T or $2,4,5$-trichloro- phenol, and few have examined separately the effects of exposure to phenoxy acids uncontaminated by $2,3,7,8-T C D D$. This is an important question since, in Britain, 2,4-D and MCPA have been used on a much larger scale than 2,4,5-T and are a major factor in the current high levels of agricultural output. A separate analysis for phenoxy herbicides uncontaminated by 2,3,7,8-TCDD was possible in one of the early Swedish case-referent studies (2), and it revealed an association with soft tissue sarcoma, although the relative risk of 4.2 was less than that for all phenoxy acids combined. Otherwise, the only relevant epidemiologic data come from a recent study of MCPA manufacturers in Denmark (14). Five cases of soft tissue sarcoma were observed in male employees at two factories followed between 1947 and 1982. When compared with the 1.84 cases expected, these five cases gave a relative risk of 2.72 with a $95 \%$ confidence interval of $0.88-6.34$. A confounding effect of 2,3,7,8-TCDD could not be entirely ruled out because, for part of the period of study, 2,4,5-T was processed at the factory where the five cases occurred. However, it was only handled on a very limited scale.

A similar limitation applies to our study also, but any such confounding would only be relevant in the context of positive findings. Coincident exposure to 2,4,5-T could not obscure a carcinogenic effect of other phenoxy acids.

Overall mortality in our cohort was less than that expected from national rates. This occurrence may be due in part to a healthy worker effect, but the low death rates from causes such as respiratory disease may also reflect the rural residence of the workforce. When adjustment was made for urban/rural differences in 
disease frequency, most of the SMR values increased, and the deficit of deaths from neoplastic disease became a small excess.

Only one death from soft tissue sarcoma was recorded, the expected number of fatalities being 0.9 in the complete cohort and 0.6 among workers potentially exposed to phenoxy acids. Independent expert review confirmed that the tumor was a neurilemmal sarcoma. No further cases were found on detailed scrutiny of the death certificates, and none were registered among living members of the cohort. However, given the incompleteness of cancer registration in Britain, especially during the early years of the follow-up period, it is possible that a nonfatal case could have gone unrecorded. There is also a possibility that one or more soft tissue tumors have been missed because they were incorrectly diagnosed - the differentiation of sarcomas from anaplastic carcinomas is often far from easy - or because a death was assigned simply to cancer without specification of the histology. Unfortunately, it would not have been practical to review the histopathology of all cancers diagnosed in the study cohort, but we were able to obtain histological material from the two patients whose deaths were ascribed to retroperitoneal tumors. Neither of these cancers was a soft tissue sarcoma.

The other cancer which has previously been linked with exposure to phenoxy acids is malignant lymphoma (6). In our study, however, Hodgkin's disease and nonHodgkin's lymphoma both caused fewer deaths than expected.

Several tumors occurred more frequently than in the general population, but the excesses were small and may well have arisen by chance. The highest SMR was for cancer of the nose and nasal sinuses, from which there were three deaths, all in subjects with potential exposure to MCPA. We are unaware of any cases of nasal cancer in other cohort studies of phenoxy herbicide workers, and, although an association between phenoxy acids and tumors of the nose and nasopharynx has been reported in a case-referent study, the relative risk was only 2.1 and not statistically significant (7). It is also relevant that one of the subjects who died from nasal cancer was stated on his death certificate to have worked most recently as a carpenter, an occupation known to carry a risk of nasal carcinoma (9). In view of this finding, and the small number of cases underlying the association, interpretation should be cautious.

The excess of deaths from multiple myeloma and leukemia is also of interest, but again has not been a consistent finding in other studies.

The importance which can be attached to the negative findings of this investigation hinges on the extent to which the workforce under examination was exposed to phenoxy acids. Unfortunately, no measurements of exposure were available for the period of study. In contrast to the processes used by some companies, production of MCPA was carried out entirely in the liquid phase and did not entail a flaking or drying operation where high levels of dust may be produced. On the other hand, in the early years of production and herbicide application, hygiene was not a major priority, and cumulative exposure to MCPA is likely to have been higher in this group of workers than in any industrial cohort of comparable size in the United Kingdom.

The results do not exclude the possibility that MCPA is a human carcinogen. In particular, the small cluster of nasal cancers will require further evaluation in the light of other investigations currently in progress. However, the findings suggest that, if there is a hazard of soft tissue sarcoma due to MCPA, then the risk is less than that suggested by earlier studies of $2,4,5-\mathrm{T}$ and 2,4,5-trichlorophenol, and it is small in absolute terms.

\section{Acknowledgments}

We thank the staff of the National Health Service Central Register and the Department of Health and Social Security for their help in tracing subjects and Dr C Du Boulay, who reviewed the histology of possible soft tissue sarcomas.

\section{References}

1. Coggon D, Acheson ED. Do phenoxy herbicides cause cancer in man? Lancet 1 (1982) 1057-1059.

2. Eriksson M, Hardell L, Berg NO, Moller T, Axelson O. Soft-tissue sarcomas and exposure to chemical substances: A case-referent study. Br J Ind Med 38 (1981) 27-33.

3. Fingerhut MA, Halperin WE, Honchar PA, Smith AB, Groth DH, Russell WO. An evaluation of reports of dioxin exposure and soft tissue sarcoma pathology among chemical workers in the United States. Scand J Work Environ Health 10 (1984) 299-303.

4. Greenwald P, Kovasznay B, Collins DN, Therriault G. Sarcomas of soft tissue after Vietnam service. J Natl Cancer Inst 73 (1984) 1107-1109.

5. Hardell L. Soft tissue sarcomas and exposure to phenoxy acids: A clinical observation. Lakartidningen 74 (1977) 2753-2754.

6. Hardell L, Eriksson M, Lenner P, Lundgren E. Malignant lymphoma and exposure to chemicals, especially organic solvents, chlorophenols and phenoxy acids: A case-control study. Br J Cancer 43 (1981) 169-176.

7. Hardell L, Johansson B, Axelson O. Epidemiological study of nasal and nasopharyngeal cancer and their relation to phenoxy acid or chlorophenol exposure. Am J Ind Med 3 (1982) 247-257.

8. Hardell L, Sandstrom A. Case-control study: Soft-tissue sarcomas and exposure to phenoxyacetic acids or chlorophenols. Br J Cancer 39 (1979) 711-717.

9. Hernberg S, Westerholm P, Schultz-Larsen K, Degerth R, Kuosma E, Englund A, Engzell U, Sand Hansen H, Mutanen P. Nasal and sinonasal cancer. Scand J Work Environ Health 9 (1983) 315-326.

10. Honchar PA, Halperin WE. 2,4,5-T, trichlorophenol and soft tissue sarcoma. Lancet 1 (1981) 268-269.

11. International Agengy for Research on Cancer. Some fumigants, the herbicides 2,4-D and 2,4,5-T, chlorinated dibenzodioxins and miscellaneous industrial chemicals. 
Lyon 1977. (IARC monographs on the evaluation of the carcinogenic risk of chemicals to man, volume 15).

12. Kociba RJ, Keyes DG, Beyer JE, Carreon RM, Wade CE, Dittenber DA, Kalnins RP, Frauson LE, Park CN, Barnard SD, Hummel RA, Humiston CG. Results of a two-year chronic toxicity and oncogenicity study of 2,3,7,8-tetrachlorodibenzo-p-dioxin in rats. Toxicol Appl Pharmacol 46 (1978) 279-303.

13. Lathrop GD, Moynahan PM, Albanese RA, Wolfe WH. An epidemiologic investigation of health effects in airforce personnel following exposure to herbicides: Baseline mortality study results. United States Air Force School of Aerospace Medicine, Brooks Air Force Base, Texas 1983.

14. Lynge E. A follow-up study of cancer incidence among workers in manufacture of phenoxy herbicides in Denmark. Br J Cancer 52 (1985) 259-270.
15. Royal Commission on the Use and Effects of Chemical Agents on Australian Personnel in Vietnam. Final report July 1985. Volume 4. Australian Government Publishing Service, Canberra 1985.

16. Smith AH, Pearce NE, Fisher DO, Giles HJ, Teague CA, Howard JK. Soft tissue sarcoma and exposure to phenoxyherbicides and chlorophenols in New Zealand. J Natl Cancer Inst 73 (1984) 1111-1117.

17. Van Miller JP, Lalich JJ, Allen JR. Increased incidence of neoplasms in rats exposed to low levels of $2,3,7,8$ tetrachlorodibenzo-p-dioxin. Chemosphere 9 (1977) $537-544$.

Received for publication: 21 March 1986 